\title{
Seroprevalence, risk factors and attitude to HIV-1 in a representative sample of lesbians in Turin
}

\author{
R Raiteri, R Fora, P Gioannini, R Russo, A Lucchini, M G Terzi, D Giacobbi, A Sinicco
}

\begin{abstract}
Objective-To estimate the HIV-1 seroprevalence, behavioural risks and attitude to HIV-1 infection among lesbians. Setting-Institute of Infectious Diseases, University of Turin, Italy.

Subjects-From March 1992 to May 1993, 181 lesbians were tested for HIV-1 and included in the study.

Methods-Sociodemographic details, nonsexual risks for HIV-1, sexual behaviour, STD history and attitude to HIV-1 were obtained from an anonymous, standardised, self-administered, 30-item questionnaire. Snow-ball techniques were used to recruit the largest possible number of participants.
\end{abstract}

Results-11 lesbians (6.1\%) were found to be HIV-1 antibody positive. Of them, 10 were intravenous (IV) drug users. STD episodes were higher among lesbians with HIV-1 than without $(p=0.04)$, increasing in both groups over time. Syphilis, genital herpes and viral hepatitis were highly associated with HIV-1 (p $=0.000$ ). In univariate analysis, IV drug use, bisexual behaviour, history of STDs, sex during menses and vaginal/anal manipulation were significantly linked to HIV-1 $(p=0.000)$. In multivariate analysis only history of IV drug use $(p=0.04)$ and bisexual behaviour $(p=0.06)$ remained independently associated with HIV-1. Seventy-one participants (39.3\%) had already undergone AIDS testing. Only $3.5 \%$ admitted to be at risk for HIV1 and $11 \%$ changed their sex habits after first hearing of AIDS. No lesbian had ever practised safe-sex. Television was the most important source of information on HIV-1 (84\%).

Conclusion-IV drug use was the most likely means of HIV-1 infecting the lesbians of Turin. The high rate of STDs and the low perceived risk to HIV-1 require programmes of STD prevention and AIDS information to be targeted at the lesbian community.

(Genitourin Med 1994;70:200-205)

Ward A, Amedeo

Savoia Hospital,

Turin, Italy

D Giacobbi

Correspondence to: Dr Alessandro Sinicco, Istituto di Malattie Infettive dell'Universitá di Torino, Ospedale Amedeo di Savoia Corso Svizzera 164, 10149 Torino, Italia.

Accepted for publication 23 February 1994
So far there have been few epidemiological studies of HIV-1 infection among lesbians. Only a few cases of female-to-female transmission of HIV-1 have been reported. Intravenous drug use, bisexual behaviour and blood transfusion are the highest risks for HIV-1 among lesbians, but it is accepted that lesbian sex may expose them to the virus. Few studies so far have reported data on these topics. The type and the prevalence of risk behaviour among lesbians remain unknown. This lack of knowledge and the low perceived risk for HIV-1 may lead to an underestimation of the extent of the link between HIV-1 and lesbians. With little hope, at present, for a cure or vaccine, risk reduction is a public health problem that must be addressed by primary prevention. Thus it is essential to acquire a better understanding of risk factors for AIDS and the attitude to HIV-1 in lesbians, in order to implement preventive strategies. The aim of the study was to evaluate the HIV-1 seroprevalence of a representative sample of lesbians in Turin and to highlight their HIV-1-related risk factors.

\section{Subjects and methods}

Sampling procedure and data collection

The study population was recruited between March 1992 and May 1993 through dissemination of information about the research in drug treatment centres, hospital wards, lesbian organisations, local newspapers and television. Snow-ball techniques were used to recruit the largest possible number of lesbians and the participants were encouraged to refer eligible friends to the study staff. Inclusion criteria were being resident in Turin, selflabelling as lesbian and compiling an anonymous, standardised, self-administered, 30-item questionnaire. On entry each participant was tested for antibody to HIV-1. The questionnaire was initially validated with 15 lesbians and changes in both the structure and the content were made in order to ensure reliability.

Five groups of variables were assessed: sociodemographic characteristics, nonsexual risks for HIV-1, sexual behaviours, venereal history and attitude to HIV-1 Sociodemographic details included age, education, profession, minor tranquillisers assumption and alcohol consumption. Information on nonsexual risks for HIV-1 was assembled on tattoing, blood transfusion, blood derivates administration and drug injecting activity, including frequency of injection, type of drug (heroin, cocaine, amphetamine), age at first injection, years of activity and needle risk behaviour (sharing needles). Sexual behaviours were evaluated by using questions on the sexual orientation, age of 
homosexual debut, ways and places of meeting partners, number of partners, types and frequency of sex acts. Participants were also questioned about survival sex (the exchange of sex for money, drugs, food or shelter) and their venereal history. The questions on drug injecting activity, sex practices and STD history were concentrated on the period 1985-92. Attitude to HIV-1 was studied by using 15 true/false questions on HIV-1 transmission and prevention. Difficulties in interpreting the questionnaire were solved by the study staff. The study was carried out individually and anonymously to preserve confidentiality. Each participant was assigned a personal code through which she could gain access to her serological status and obtain counselling, if desired.

\section{Laboratory methods}

HIV-1 testing was carried out by both Wellcozyme HIV Recombinant (Wellcome Diagnostics, Dartford, England, UK) and Anti-HIV, HTLVII/LAV EIA 'Roche' (Hoffman-La Roche Ltd, Basel, Switzerland) kits and was confirmed by Western blot (DuPont De Nemours, DuPont Company, Wilmington, Delaware, USA).

\section{Statistical analysis}

Results were expressed as mean, standard deviation (SD). Categorical data were evaluated by using chi square and Fisher's exact test; nonparametric tests were used to analyse the continuing data. Odds ratios (ORs) and $\log$-ORs were used to estimate the strength of the link between HIV-1 and each pertinent variable. Multiple logistic regression analysis was used to estimate the effect of multiple factors simultaneously on the ORs for HIV-1. Data were processed with SPSS (Statistical Package for Social Studies) software, version 4.0 (SPSS Inc., Chicago, Illinois, USA), CSS (Complete Statistical System) software (StatSoft, Tulsa, Oklahoma, USA) and CIA (Confidence Interval Analysis), statistical package, version 1·1 (BMJ, London, England, UK).

\section{Results}

From March 1992 to May 1993, 181 lesbians were recruited. Eleven $(6 \cdot 1 \%)$ had evidence of HIV-1 infection. Of them, seven belonged to the category A 1 , three to the A 2 and one to the B 2 according to the 1993 revised CDC classification. $^{1}$

\section{Sociodemographic characteristics}

Sociodemographic profile and nonsexual risk factors for HIV-1 are shown in table 1. The mean age was 27.9 , SD $5 \cdot 2$ yrs (range: 17-40). Most of the lesbians had high education $(87 \cdot 3 \%)$ and clerical work $(50 \cdot 8 \%)$. Sixty-nine (38.1\%) lived alone, $68(37 \cdot 6 \%)$ with steady female partner and $44(24 \cdot 3 \%)$ with parents. None had ever had blood transfusion or plasma products; $42(23.2 \%)$ had a tattoo; $109(60 \cdot 2 \%)$ were or had been habitual users of minor tranquilisers and 37
Table 1 Sociodemographic profile and nonsexual risk factors to $H I V-1$ of the study population $(N=181)$

\begin{tabular}{lrrrr}
\hline Variable & & $N$ & $(\%)$ \\
\hline Age, year & $27 \cdot 9$, SD 5.2 & $<18$ & 6 & $3 \cdot 3$ \\
& (range: 17-40) & $19-25$ & 57 & $31 \cdot 5$ \\
& $26-35$ & 97 & $53 \cdot 6$ \\
Education, years & $>35$ & 21 & $11 \cdot 6$ \\
& 8 & 23 & $12 \cdot 7$ \\
Profession & 13 & 127 & $70 \cdot 2$ \\
& $>17$ & 31 & $17 \cdot 1$ \\
& student & 20 & $11 \cdot 0$ \\
& manual work & 22 & $12 \cdot 2$ \\
Living situation & clerical work & 92 & $50 \cdot 8$ \\
& professional work & 32 & $17 \cdot 7$ \\
Tattoo & withemployed & 15 & $8 \cdot 3$ \\
& steady partner & 68 & $37 \cdot 6$ \\
Ethanol abuse & alone & 69 & $38 \cdot 1$ \\
IV drug use & with parents & 44 & $24 \cdot 3$ \\
Minor tranquilisers use & yes & 42 & $23 \cdot 2$ \\
& no & 139 & $76 \cdot 8$ \\
& yes & 35 & $19 \cdot 3$ \\
& no & 146 & $80 \cdot 6$ \\
& yes & 37 & $20 \cdot 4$ \\
& no & 144 & $79 \cdot 6$ \\
& yes & 109 & $60 \cdot 2$ \\
& no & 72 & $39 \cdot 8$ \\
\hline
\end{tabular}

(20.4\%) alcohol abusers. The mean weekly consumption of alcohol was $661,112 \mathrm{~g}$ (5.9, $1.3 \mathrm{~L}$ of beer, $2.5,0.8 \mathrm{~L}$ of wine and $0.22,0.4$ $\mathrm{L}$ of liquor). The lesbians with history of IV drug use had a higher alcohol consumption ( $p$ $=0.000$ ). While there was no statistical association between alcohol consumption and HIV-1, there was a significant link to history of STDs $(p=0.05)$. Thirty-seven $(20.4 \%)$ reported use of IV heroin, $16(43.2 \%)$ of cocaine and/or amphetamine by non injection route. Most of them $(70 \cdot 2 \%)$ were nonoccasional users and often shared parenteral drug $(81 \cdot 1 \%)$; only four admitted having had drug abuse treatment programmes.

\section{Sexual and venereal characteristics}

As can be seen in table 2, the age of homosexual initiation was 15.6, 1.7 yrs (range: 13-23). The most common meeting places were friends' houses $(28.0 \%)$, bars/discoteques $(25 \cdot 3 \%)$ and lesbian associations $(22 \cdot 2 \%)$. Only 12 lesbians $(6 \cdot 6 \%)$ regularly put advertisements in local papers to find sex. Each participant identified herself as lesbian, but 35 (19.3\%) had also had heterosexual sex. Of 11 lesbians with HIV-1, two had sex with men. A clear link was seen between HIV-1 and heterosexual sex, especially after 1987

Table 2 Sexual and venereal characteristics of the study population $(n=181)$. STDs, sexually transmitted diseases

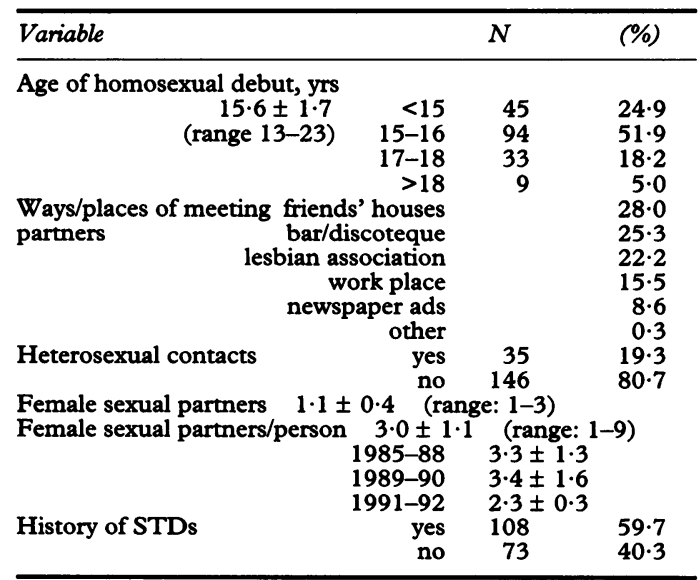


$(p=0 \cdot 000)$. Nearly two thirds $(72 \cdot 4 \%)$ of the lesbians had more than seven lifetime female partners, those with HIV-1 not differing from the seronegative. Since 1985 the mean number of sex partners and of partners/yr was 2.8 , 1.0 (range: 1-6) and 1.0, 0.6 (range: $1-3$ ), respectively. No change was observed over time. Higher number of partners was always associated with history of STDs $(p=0.000)$, and, only for the period 1991-92, with HIV-1 $(p=0.021)$. The mean duration of a lesbian relationship was $10.2,9.1$ months (range: 2-48), with no difference between IV drug users (IDUs) and non-IDUs nor lesbians with HIV-1 and without. No association emerged between the length of the relationship and IV drug abuse, history of STDs or HIV-1.

\section{Lesbian IDUs: demographic and behavioural} details

Table 3 shows the age and the behavioural details of IV drug use and homosexuality in 37 lesbian IDUs. The lesbians with and without HIV-1 did not differ in age, age of homosexual initiation and addiction-related characteristics. The stratification by duration of injecting practice showed that HIV-1 was closely associated with prolonged IV heroin use and IV drug addiction debut before 1985 $(p=0.000)$. Among lesbian IDUs with HIV-1 the mean time between IV use debut and the discovery of antibody to HIV-1 was $3 \cdot 8,3 \cdot 0$ years (range: $1-11$ ).

\section{Sexual frequency over time}

Most of the participants had sex every 2-3 days $(40.6 \%$ to $58.0 \%)$ or once a week $(39 \cdot 2 \%$ to $43 \cdot 5 \%)$. The lesbians younger than 26 , less educated and unemployed had the lowest sexual activity $(p=0.000)$; the highest was observed among those aged over 26 , with steady partner and high education $(p=$ $0 \cdot 000$ ). The frequency of sex over time did not differ significantly, except for the increase of lesbians having sex once every 2-3 days after $1988(p=0.000)$. The stratification of sex frequency by HIV-1 serostatus showed no difference.

Table 3 Sociodemographic and behavioural characteristics of the 37 participants with IV drug use history according to their HIV-1 serostatus

\begin{tabular}{|c|c|c|c|c|}
\hline Variable & $\begin{array}{l}\text { IDUS } \\
(n=37)\end{array}$ & $\begin{array}{l}H I V+I D U s \\
(n=10)\end{array}$ & $\begin{array}{l}H I V-I D U S \\
(n=27)\end{array}$ & $p$ \\
\hline Age, years & $\begin{array}{l}27 \cdot 6 \text { SD } 4 \cdot 4 \\
\text { (R: } 21-40)\end{array}$ & $26 \cdot 7$ SD 2.6 & 28.0 SD 4.9 & NS \\
\hline $\begin{array}{l}\text { Duration of IV } \\
\text { drug abuse, yrs } \\
\text { Intervals of } \\
\text { addiction }\end{array}$ & $\begin{array}{l}\text { 4.7 SD 2.4 } \\
(\mathrm{R}: 1-10) \\
\text { n }(\%)\end{array}$ & $\begin{array}{l}\text { 5.7 SD } 2 \cdot 8 \\
\text { n (\%) }\end{array}$ & $\begin{array}{l}\text { 4.3 SD } 2 \cdot 1 \\
\text { n (\%) }\end{array}$ & NS \\
\hline $\begin{array}{l}\text { <3 year: } \\
\text { 4-6 year: } \\
\text { >6 year: } \\
\text { IV drug } \\
\text { use debut }\end{array}$ & $\begin{array}{l}16(43 \cdot 2) \\
12(32 \cdot 4) \\
9(24 \cdot 3) \\
\mathrm{n}(\%)\end{array}$ & $\begin{array}{l}3(8 \cdot 1) \\
2(5 \cdot 4) \\
5(13 \cdot 5) \\
\text { n }(\%)\end{array}$ & $\begin{array}{l}13(48 \cdot 1) \\
10(37 \cdot 0) \\
4(14 \cdot 8) \\
\mathrm{n}(\%)\end{array}$ & NS \\
\hline $\begin{array}{l}\text { <1985: } \\
\text { 1985-1987: } \\
\text { >1987: } \\
\text { Age of homosexual } \\
\text { debut, years }\end{array}$ & $\begin{array}{l}17(45 \cdot 9) \\
11(29 \cdot 7) \\
9(24 \cdot 3) \\
15 \cdot 1 \text { SD } 1 \cdot 1 \\
(\mathrm{R}: 13-18)\end{array}$ & $\begin{array}{l}4(10 \cdot 8) \\
4(10 \cdot 8) \\
2(5 \cdot 4) \\
15 \cdot 5 \mathrm{SD} 1 \cdot 4\end{array}$ & $\begin{array}{l}13(35 \cdot 1) \\
7(18 \cdot 9) \\
7(18 \cdot 9) \\
14.9 \text { SD } 0.9\end{array}$ & $\begin{array}{l}\text { NS } \\
\text { NS }\end{array}$ \\
\hline $\begin{array}{l}\text { Age of IV drug } \\
\text { use debut, years } \\
\text { Time from IV drug use } \\
\text { debut to HIV-1 positivity, yrs }\end{array}$ & $\begin{array}{l}20 \cdot 3 \text { SD } 3 \cdot 7 \\
\text { (R: } 15-31) \\
-\end{array}$ & $\begin{array}{l}19 \cdot 5 \text { SD } 1.6 \\
(R: 17-22) \\
3 \cdot 8,3 \cdot 0 \\
(R: 1-11)\end{array}$ & $\begin{array}{l}20 \cdot 6 \text { SD } 4 \cdot 2 \\
(\mathrm{R}: 15-31) \\
-\end{array}$ & NS \\
\hline
\end{tabular}

IDUs, intravenous drug users; NS, not significant; R, range; HIV +, seropositive to HIV-1, HIV -, seronegative to HIV-1.
Table 4 Lesbian sexual practices throughout the 1985-92 years

\begin{tabular}{|c|c|c|c|}
\hline Sexual practice & $\begin{array}{l}1985-88 \\
(\%)\end{array}$ & $\begin{array}{l}1989-90 \\
(\%)\end{array}$ & $\begin{array}{l}1991-92 \\
(\%)\end{array}$ \\
\hline $\begin{array}{l}\text { Anal manipulation } \\
\text { Cunnilingus } \\
\text { Sex during menses } \\
\text { Reciprocal exchange } \\
\text { of sexual devices }\end{array}$ & $\begin{array}{l}41 \cdot 9 \\
95 \cdot 1 \\
90 \cdot 2 \\
72 \cdot 0\end{array}$ & $\begin{array}{l}46 \cdot 8 \\
\text { all } \\
93 \cdot 0 \\
78 \cdot 3\end{array}$ & $\begin{array}{l}46 \cdot 1 \\
\text { all } \\
95 \cdot 1 \\
77 \cdot 6\end{array}$ \\
\hline Group sex & $4 \cdot 2$ & $4 \cdot 1$ & $4 \cdot 2$ \\
\hline
\end{tabular}

The results are expressed as a cumulative percentage of lesbians engaging in specific sexual acts during the considered period. All the lesbians practised deep kissing, breast fondling and mutual masturbation.

\section{Sexual practices over time}

Table 4 shows the percentage of lesbians having specific sex acts since 1985. Each woman practised deep kissing, breast fondling and mutual masturbation. Less than half engaged in anal manipulation and a very small number in group sex, but both these sexual practices increased over time. Nearly all the lesbians had sex during menses $(90 \cdot 2 \%$ to $95 \cdot 1 \%)$ and all practised cunnilingus regularly, especially after 1988. Despite these variations, the sex practices throughout 1985-1992 remained statistically unchanged. Only 18 lesbians $(9.9 \%)$ had knowledge of safe-sex and none had ever used dental dams. No lesbian who had sex with men had ever used condom. Only one lesbian with HIV-1 admitted survival sex. Forty-four lesbians $(24 \cdot 3 \%)$ had sex with non-Italian female partners. These relationships were significantly more frequent among lesbians living alone or with steady partner, with age over 26, professional job, high education $(p=0.000)$ and history of STDs $(p=0.001)$. Three lesbians with HIV 1 had sex with non-Italian partners, but no significant link to HIV-1 was found. American and Spanish women $(15 \cdot 1 \%$ and $9 \cdot 6 \%)$ were the most frequent partners, African and English the most sporadic $(2 \cdot 3 \%$ and $1 \cdot 7 \%)$.

\section{STD episodes}

One hundred and eight lesbians $(59.6 \%)$ had at least one episode of STD. Ten lesbians with HIV-1 (90.9\%) and 98 without $(56.4 \%)$ had history of STDs. STD episodes were higher among lesbians without HIV-1 ( $p=$ $0.04)$, increasing over time ( $n=9$ in 1985, $n$ $=79$ in $1987 ; p=0.000)$. Genital herpes, viral hepatitis and vaginitis were the most frequent STD in this group. Similarly, STD episodes increased over time among the lesbians with HIV-1 (one before 1985, 14 after 1987; $p=0.000)$. A strong association between STD and HIV-1 was seen, the highest with syphilis, viral hepatitis and genital herpes $(p=0.002$ to 0.000$)$. The number of lesbians who had more than one STD episode was higher in the group with HIV-1 $(p=0.021)$. Genital herpes and viral hepatitis were more frequent as debut STD $(p=0.029)$. Syphilis and viral hepatitis were more common among lesbians with recurrent STDs and both significantly associated with HIV-1 $(p=0.000)$. No link was seen between HIV-1 and year of STD manifestation, while sex during menses was related to history of syphilis $(p=0.02)$. 
Viral hepatitis and genital herpes were associated with history of sex with non-Italian partners $(p=0.04)$; unchanged sex habit was more likely to be linked to recurring STDs $(p=0.05)$; history of STDs to living alone or with parents $(p=0.04$ and $p=0.014)$. Genital herpes and vaginitis were significantly linked to higher income, syphilis and viral hepatitis to lower. Syphilis and viral hepatitis were highly associated with IV drug abuse ( $p$ $=0.015$ and $p=0.000$ ). Among lesbian IDUs and those having had sex with men, syphilis was the most frequent as debut STD $(p=$ 0.027 and 0.000 ), while genital herpes and viral hepatitis as subsequent STDs $(p=0.001$ and $p=0.000$ ). All of lesbian IDUs had viral hepatitis and/or genital herpes. No correlation was seen between the mean number of sex partners and STDs.

\section{Attitude to HIV-1 infection}

On entry, 71 lesbians (39.3\%) had already had an AIDS test, most of them (70.1\%) between 1986 and 1987. All those with HIV-1 had already been tested (five in 1985, three in 1986 and three in 1987). As for the year of first knowledge of HIV-1, most of the lesbians first heard about AIDS between 1985 and $1987(90.0 \%)$, with no difference between the lesbians with and without HIV-1. History of IV drug abuse and STDs were not associated with year of first AIDS knowledge. The lesbians aged over 26, with high education and professional job knew of HIV-1 earlier than those younger, less educated and unemployed $(p=0 \cdot 06)$. Regarding the reasons why they had never had an HIV-1 test, the great majority refused because they assumed that they were not at risk for HIV-1 (85.0\%); a small minority considered the test unreliable $(12.6 \%)$ or doubted its anonymity $(11 \cdot 5 \%)$. The lack of trust in the test was significantly related to low education $(p=0.003)$, whilst the fear of the result to age over 26 and professional job $(p=0.007)$. The percentage of lesbians responding correctly to 15 true/false questions on HIV-1 transmission and prevention was high. One hundred and twenty eight $(89.0 \%)$ scored $>12 / 15$ right answers. The rest ranged between $7 / 15$ to $10 / 15(4 \cdot 2 \%$ and $7 \cdot 2 \%)$. No correlation could be ascertained between attitude to HIV-1 and age, education or antibody to HIV-1. STD history was associated with poor information of HIV-1 ( $p=$ $0.008)$ and lower education $(p=0.021)$.

Lesbian compliance to the study was high. Basic motivation was to collaborate on highlighting the link between HIV-1 and lesbians $(44.7 \%)$ or, in general, women and AIDS $(19 \cdot 0 \%)$. Twenty-five percent firmly believed in prevention, but only $3.5 \%$ admitted to be at risk for HIV-1 and $11 \%$ changed their sexual habits after first hearing of AIDS. From the study lesbians expected detailed information on sex-related risk $(75.0 \%)$. Most of them $(79.6 \%)$ considered taking part in meetings on AIDS the most useful means to understand the HIV-1-related problems better. Looking at the origin of information on AIDS, television was the most important source
Table 5 Univariate association of drug use, sex with men, history of STDs and type of sex with seropositivity to HIV-1 among 181 lesbians

\begin{tabular}{lrll}
\hline Variable & $O R$ & $C I$ & $p^{\star}$ \\
\hline IV drug use & $53 \cdot 0$ & $6 \cdot 5-431$ & $0 \cdot 000$ \\
Heterosexual sex & $14 \cdot 1$ & $3 \cdot 5-56 \cdot 7$ & $0 \cdot 000$ \\
History of STDs & $7 \cdot 3$ & $0 \cdot 9-58 \cdot 7$ & 0.029 \\
Syphilis & $48 \cdot 0$ & $7 \cdot 5-308$ & 0.000 \\
Viral hepatitis & 16.2 & $4 \cdot 0-65 \cdot 5$ & 0.000 \\
Genital herpes & $11 \cdot 4$ & $2 \cdot 4-55$ & 0.000 \\
Sex during menses & 4.3 & $1 \cdot 1-16 \cdot 8$ & 0.000 \\
Vaginal/anal manipulation & 3.6 & $0.9-14 \cdot 2$ & 0.000 \\
\hline
\end{tabular}

^Fisher's exact test; OR, Odds ratio; CI, 95\% confidence interval.

Table 6 Multiple logistic regression analysis of the association of HIV-1 infection with drug use, sex with men, history of STDs and sexual practices among 181 lesbians

\begin{tabular}{llrrl}
\hline Variable & $\beta$ & OR & \multicolumn{1}{l}{$C I$} & $p$ \\
\hline IV drug use & 3.4 & $29 \cdot 7$ & $1 \cdot 1-798$ & .04 \\
Heterosexual sex & $2 \cdot 2$ & $9 \cdot 3$ & $0 \cdot 9-98 \cdot 2$ & .06 \\
History of STDs & $2 \cdot 3$ & $9 \cdot 9$ & $0 \cdot 1-925$ & NS \\
Syphilis & 0.6 & $1 \cdot 8$ & $10 \cdot 5-62 \cdot 2$ & NS \\
Viral hepatitis & $1 \cdot 4$ & $4 \cdot 0$ & $0 \cdot 2-56 \cdot 7$ & NS \\
Genital herpes & $2 \cdot 2$ & $9 \cdot 0$ & $0 \cdot 4-208$ & NS \\
Sex during menses & 0.5 & 1.6 & $0 \cdot 1-18.4$ & NS \\
Vaginal/anal manipulation & 1.9 & 6.7 & $0 \cdot 5-87 \cdot 1$ & NS
\end{tabular}

OR, Odds ratio; $\mathrm{CI}, 95 \%$ confidence interval; NS, not significant.

(84.0\%), magazines and printed media the second largest one $(13 \cdot 7 \%)$. Doctors and health care organisations were mentioned only by $1 \cdot 3 \%$.

Univariate and multivariate analyses

As can be seen in Table 5 , in the univariate analysis higher risk factors for HIV-1 included IV drug abuse, heterosexual contacts, history of STDs, sex during menses and vaginal/anal manipulation $(p=0.000)$. Syphilis, viral hepatitis and genital herpes were closely related to HIV-1 $(p=0.000)$. In a multivariate model using antibody to HIV-1 as the outcome variable (table 6), the only variable independently linked to HIV-1 was IV drug abuse $(p=0.04)$, sex with men being only of borderline significance $(p=0.06)$.

\section{Discussion}

Sexual transmission is predominant in the global epidemiology of HIV-1 ${ }^{2}$, but only some aspects are known. Several studies have estimated the magnitude and the determinants of the risk associated with sex among homosexual males and heterosexuals. ${ }^{3-7}$ By contrast, very little is known about HIV-1 and lesbians. Articles addressing lesbians are infrequent and those few are either case reports or partial studies. $^{8-15}$ Different factors are responsible for this. Lesbians very often are an ignored group, surrounded by misunderstanding and curiosity at the best, or suspicion and open hostility at the worst. ${ }^{16}$ On the other hand, very few instances of female-to-female sexual transmission of HIV-1 have been reported. To date, sexual transmission appears to be an extremely rare event among lesbians. Moreover the deep-rooted idea of not being at risk has also played an important role in keeping them an unstudied group. Finally the rad- 
icalism of some lesbian associations has made it difficult to include them in epidemiological surveys. Recent articles, however, have reported more than 100 cases of HIV-1 antibody seropositivity and 164 cases of AIDS in American lesbians. It is becoming increasingly evident that lesbians with HIV-1 exist, even if most of them have not been infected through sex. $^{10}$

This study tried to detail the seroprevalence, the risk behaviours and attitude to HIV-1 among lesbians in Turin, an industrial, northern Italian city, with roughly $1,000,000$ inhabitants and a high rate of HIV-1 infection, especially among IDUs.

Before commenting on the results, however, some methodological issues merit discussion. First, because of the self-administered questionnaire, the reliability of the responses may be questionable. We chose this approach to minimalise embarassment or reluctance to answer. To avoid bias of self-reported data because of intentional nonreporting, incomplete recall, misinterpretation of the questions or pressure to give socially desirable answers, the main topics were cross-checked by repeating the same question in other terms. Second, we think that the sample is large and consistent enough to offer useful and correct insight into the lesbian population in Turin. The extensive promotion of the study, the high compliance of lesbians and the wide spectrum of the sampling sources guarantee the reliability of the sample. The recruitment criteria ensure that the participants will reflect the lesbians of Turin, but it is unknown if the results can be generalised to other lesbian communities. A third potential problem is the small statistical power due to the low HIV-1 seroprevalence rate in the sample and the presence of confounding factors, such as the large IV drug use among lesbians with HIV-1. However, since the data presented in this paper are difficult to obtain, it is believed that it is important to describe the behaviour of this specific population, although the external validity of the results may be limited.

IV heroin use more than bisexual behaviour resulted as the most likely means of HIV-1 infecting lesbians. Therefore, it is important to underline that sex partners of lesbian IDUs may be at higher risk for HIV-1. The knowledge of sexual behaviour is fundamental to understand the extent of the lesbian sexassociated risk. However, this risk is not clear either because the lesbian sex has not been studied or because it is difficult to isolate these acts for evaluation. Although lesbian sex was not associated with HIV-1 in the multivariate model, it should be noted that it cannot be eliminated as a possible transmission mode. The low rate of HIV-1 seroprevalence and the widespread IV drug use did not provide the necessary statistical power to reject the possibility of the even non-significant risk demonstrated for some practices. This fact is stressed by the upper boundaries of the $95 \%$ confidence intervals for the odds ratio from sex during menses and genital manipulation.

HIV-1 has been isolated from genital secretion of seropositive women. ${ }^{17-21}$ Thus, viral transmission may occur during contact with these secretions. Worth noting is that nearly the whole study population had sex during menses and practised cunnilingus as well as mutual masturbation sometimes with shared sexual toys. To date, there is only one case report of HIV-1 infection in a lesbian who had history of oral-genital sex. ${ }^{22}$ In another case report, a woman became HIV-1 positive possibly as a result of a relationship with a HIV-1 lesbian IDU. She reported digital and anal contacts during her partner's menses and both women had vaginal bleeding because of trauma due to sexual toys. ${ }^{23}$ The discrepancy between high-risk lesbian sex and low HIV-1 transmission is intriguing and parallels partially the lower efficiency of female-to-male compared with male-to-female transmission. ${ }^{24-26}$ Some factors may decrease the frequency of HIV-1 transmission through lesbian sex. Antibodies to HIV-1 in the vaginal mucosa and inhibitory capacity of human saliva are well documented. ${ }^{17-19} 27$ Both these mechanisms may somewhat foil the efforts of HIV-1 to colonise host cells, especially in the presence of low viral load and minor sexual trauma. The trauma of the vaginal mucosa during lesbian sex compared with heterosexual is usually lower, except for the use of sexual toys, when bleeding and mucosal injuries are frequent and represent favourable route for HIV-1 infection..$^{23}$ It cannot be excluded that the low number of lesbians with HIV-1 despite high-risk sex may also depend on increased care of the HIV-1 lesbians when having sex with their partners. This comfortable explanation, however, does not seem to apply to our subjects who answered controversially about change of their sex habits. Finally, a lower susceptibility to HIV-1, already hypothesised in heterosexual couples, may also be suggested for lesbians and linked to genetic factors. ${ }^{28}$

Of interest was the high rate of STDs among the participants. This result, in contrast with previous investigations, is consistent with recent reports. ${ }^{29-31}$ Although both HIV-1 negative and positive lesbians had significant increase of STDs over time, it could be detected earlier in those with HIV-1. The years $1985-87$ have seemingly been critical for HIV-1 infection among the participants. Interestingly, HIV-1 diffusion was very high in Turin during those years, in particular among IDUs. People with HIV-1 are also at higher risk for STDs and the epidemiological synergy between the pathogens responsible for STDs and HIV-1 is clear. ${ }^{32-33}$ As a result, the prevention of HIV-1 among lesbians is inextricably intertwined with the control of STDs.

Noteworthy, but not surprising, was the link between age over 26 years, high education, professional job and higher sex activity. These conditions, in fact, offer higher sex opportunity. They also account for the link between higher sex with non-Italian partners 
and the above sociodemographic characteristics.

In the years of 2 IDS epidemic one might have expected that concern about HIV-1 would have substantially changed sex behaviour. Our findings do not support this, but indicate that public health campaign has not had a substantial influence on lesbian habits. These findings focus on the fact that despite the existence of emerging infectious disease, lesbians have not changed the frequency and the types of sex over time. Moreover the increase, even if not statistically significant, of some sexual practices over time emphasise the presumption of lesbians that they are not at risk for HIV-1. This distressing perception was largely present in the study population with no difference of age, education and profession..$^{1215}$ Accordingly it transpires that HIV -1 is assumed to be a problem outside the lesbian community. Such a reasoning is very dangerous because it may generate the erroneous notion that lesbians are unrelated to HIV-1 and have no need to adhere to warnings for HIV-1 prevention. This finding, together with the poor knowledge of safe-sex techniques magnifies even more its importance when considering the high rate of STDs among the participants. ${ }^{34}$

The low number of sex partners among the lesbians was surprising. This result, in contrast with other reports, more than awareness of the risk associated with multiple sex partners is likely to be due to the intrinsic characteristics of Turin lesbian community: a relatively small size, difficulty in living openly, fear of external reactions, limited meeting places. The discrepancy between the low number of sex partners and the high rate of STDs raises conflicting hypotheses. Not only does it suggest low circulation of HIV-1 among lesbians, strictly confined to those with history of IV drug use, but also supports the existence of an effective system against HIV-1 transmission through lesbian sex. The relatively low rate of HIV-1 and the high presence of ulcerative STDs in both HIV-1 positive and negative lesbians seem to validate the latter hypothesis. In conclusion, IV drug use appears to be the most frequent mode of HIV1 entering the lesbian population. Arresting HIV-1 in IDU lesbians and fighting the low perceived risk for AIDS are of utmost importance. Thus combined programmes of STD prevention and specific efforts for extensive information on AIDS should be tailored to lesbians.

We are indebted to all those who agreed to participate in the study. We thank M.L., E.P. and R.P. for their invaluable help in preparing the questionnaire and Ms C. Niknejan for the revision of the manuscript. All the lesbian associations are also gratefully acknowledged for their thoughtful comments. This research has been supported by the $\mathrm{C}$. Denegri Foundation, Turin, Italy.

11993 Revised Classification System for HIV Infection and Expanded Surveillance Case Definition for AIDS among Expanded Surveillance Case Definition for AIDS am
adolescents and adults. $M M W R, 1993 ; 41: R R ~ 17$.

2 Piot $P$, Laga $M$, Ryder $R$, et al. The global epidemiology of HIV infection: continuity, heterogenity, and change. f Acquir Immune Defic Synd 1990;3:402-12.

3 Winkelstein W, Lyman DM, Padian N, et al. Sexual practices and risk of infection by the human immuno- deficiency virus. $\mathscr{f} A M A, 1987 ; 257: 321-5$

4 Chiasson MA, Stoneburner RL, Lifson AR, et al. Risk factors for immunodeficiency virus type 1 (HIV-1) infection in patients at a sexually transmitted disease clinic in New York City. Am $\mathcal{F}$ Epidemiol, 1989;131 208-20.

5 Moss AR, Osmond D, Bacchetti P, Chermann JC, BarreSinoussi F, Carlson J. Risk factors for AIDS and HIV seropositivity in homosexual men. Am $\mathcal{F}$ Epidemiol, 1987 125:1035-47.

6 Harris C, Small CB, Klein RS, et al. Immunodeficiency in female sexual partners of men with the acquired immunodeficiency syndrome. $N$ Engl f Med 1983;308: 1181-4.

7 Peterman TA, Stoneburner RL, Allen JR, Jaffe HW, Curran JW. Risk of human immunodeficiency virus transmission for heterosexual adults with transfusionassociated infections. $¥ A M A, 1988 ; 259: 55-8$.

$8 \mathrm{Chu}$ SY, Buehler JW, Fleming PL, Berkelman RL. Epidemiology of reported cases of AIDS in lesbians, United States 1980-89. Am f Public Health, 1990;80 1380-1.

9 Dicker BG. Risk of AIDS among lesbians. Am f Public Health, 1989;79:1569.

10 Chu SY, Hammet TA, Buehler JW. Update: epidemiology of reported cases of AIDS in women who reported sex only with other women, United States, 1980-91. AIDS 1992;6:509-22.

11 Hunter J, Rotheram-Borus MJ, Reid H, Rosario H. Sexual and substance abuse acts that place lesbians at risk for HIV. Int Conf AIDS, 1992, 19-24 July, Abstract no. PoD5208.

12 Russel MA, Alcober J, McKinley P. The perception of risk for HIV infection among lesbians in New York City. Int Conf AIDS 8(2) 1992 19-24 July, abstract no. PoD Conf .

13 Sasse H, Iardino $R$, Codice A, Gherardi C, Forchi F Chiarotti F. Potential routes of HIV transmission among women engaging female-to-female sexual practices. In Conf AIDS 1992 19-24 July, abstract no. PoD 5209.

14 Sanders SA, Reinisch JM, Ziemba-Davis M. Self-labeled sexual orientation and sexual behaviour among women. Int Conf AIDS 1989 4-9 June, abstract no. TDP 75.

15 Ribble D, Marte C, Kelly J, Keyes C, Rodgers P, Walbert J. HIV infection in lesbians Int Conf AIDS 1989 4-9 June, abstract no. WAP 10.

16 Randall CE. Lesbian phobia among BSN educators: a survey. $\mathcal{F}$ Nurs Educ 1989;28:302-6.

17 Archibald DW, Witt DJ, Craven DE, Vogt MW, Hirsch MS, Essex M. Antibodies to human immunodeficiency virus in cervical secretions from women at risk for AIDS. virus in cervical secretions from

18 Belec L, Georges AJ, Steenman G, Martin PMV Antibodies to human immunodeficiency virus in vagina secretions of heterosexual women. $\mathcal{F}$ Infect Dis 1989 160:385-91.

19 Belec L, Peghini M, Georges AJ, Barabe P, Martin PMV Antibodies to HIV-2 in genital secretions. Res Virol 1989;140:15-21.

20 Vogt MW, Witt DJ, Craven DE, et al. Isolation of HTLVIII/LAV from cervical secretions of women at risk for AIDS. Lancet 1986;i:525-7.

21 Wofsy CB, Hauer LB, Michaelis BA, et al. Isolation of AIDS-associated retrovirus from genital secretions of women with antibodies to the virus. Lancet 1986;i: women

22 Monzon OT, Capellan JMB. Female-to-female transmission of HIV. Lancet 1987;ii:40-1.

23 Marmor M, Weiss LR, Lyden M, et al. Possible female-tofemale transmission of human immunodeficiency virus. Ann Intern Med 1986;105:969.

24 European Study Group on Heterosexual Transmission of HIV: Comparison of female to male to male to female transmission of HIV in 563 stable couples. BMF 1992 304:809-13.

25 Padian NS, Shiboski SC, Jewel NP. Female to male transmission of human immunodeficiency virus. $\mathscr{F A M A} 1991$ 226:1664-7.

26 Al-Nozha M, Ramia S, Al-Frayh A, Arif M. Female to male: an inefficient mode of transmission of human immunodeficiency virus. $f$ Acquir Immune Defic Synd immunodeficie

27 Fulz PN. Components of saliva inactivate human immuno-deficiency virus. Lancet 1986;ii: 125.

28 Padian NS. Heterosexual transmission of acquired immunodeficiency syndrome: international perspectives and national projections. Rev Infect Dis 1987;9:947-60.

29 De Fine Olivarius F, Worm AM, Petersen CS, Kroon S Lynge E. Sexual behaviour of women attending an inner-city STD clinic before and after general campaign for safer sex in Denmark. Genitourin Med 1992;68. 296-9.

30 Otten MW Jr, Zaidi-Akbar A, Wroten JE, Witte JJ, Peterman TA. Changes in sexually transmitted diseases after HIV testing and posttest counseling, Miami, 1988 to 1989. Am $\mathcal{F}$ Public Health 1993;83:529-33.

31 Hinman AL, Willard C Jr. Sexually transmitted diseases in the 1990s. N Engl $f$ Med 1991;325:1368-70.

the 1990s. N Engl f Med 1991;325:1368-70.
32 Savell R, Valls S, Cabre M. Syphilis and HIV infection. Genitourin Med 1991;67:353.

33 Kreiss JK, Koech D, Plummer FA, et al. AIDS virus infection in Nairobi prostitutes: spread of the epidemic to East Africa. $N$ Engl $\mathcal{F}$ Med 1986;314:414-8

34 Sherr L, Strong C. Safe sex and women. Genitourin Med 1992;68:32-5. 